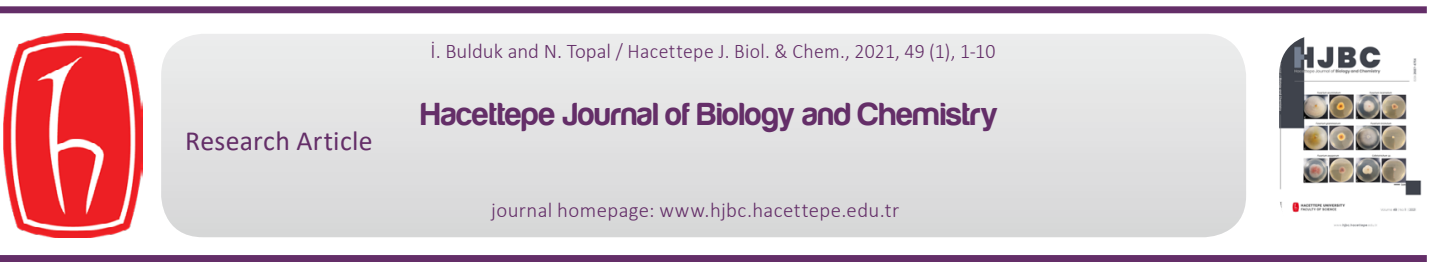

\title{
Development and Validation of a Quantification Method for L-Dopa in Plants and Pharmaceutical Materials
}

\section{Bitkilerde ve Farmasötik Materyallerde L-Dopa için Analiz Metodunun Geliştirilmesi ve Validasyonu}

\author{
İbrahim Bulduk ${ }^{1 \odot}$, Nurdoğan Topal ${ }^{2}$ \\ ${ }^{1}$ Department of Chemistry, Uşak University, Uşak, Turkey. \\ ${ }^{2}$ Department of Field Crops, Uşak University, Uşak, Turkey.
}

\section{ABSTRACT}

T-Dopa is an antiparkinsonian drug and is used per oral application. A reliable liquid chromatographic method for determination of L-Dopa in leaves, flowers and seeds of Vicia faba L. grown in Turkish habitats and pharmaceutical dosage forms has been developed. The analysis has been carried out using Ace C18 (5 $\mu \mathrm{m}, 4.6 \times 250 \mathrm{~mm}$,) column, and the separation was carried out using a mobile phase consisting of $50 \mathrm{mM}$ potassium dihydrogen phosphate $\left(\mathrm{pH}\right.$ 2.3) at a flow rate of $1.2 \mathrm{~mL} \mathrm{~min}^{-1}$ with UV detection at $280 \mathrm{~nm}$. The method has been validated according to the acceptance criteria of the $\mathrm{ICH}$ guidelines. The method demonstrated good linearity $\left(\mathrm{R}^{2}>0.999\right)$ over the assayed concentration range, good intra-day and inter-day precision. The detection limit (LOD) and the quantification limit (LOQ) values were determined as 1.70 and $5.13 \mu \mathrm{g} \mathrm{mL} \mathrm{m}^{-1}$ for L-Dopa. Developed method has been successfully used for the determination of L-Dopa in pharmaceutical formulations and plant materials.

\section{Key Words}

L-Dopa, HPLC-UV, method, calidation, plant material.

\section{öz}

\footnotetext{
T -Dopa antiparkinson ilaçtır ve oral uygulama için kullanılır. Türk habitatlarında yetiştirilen Vicia faba L.'nin yapraklarında çiçeklerinde ve tohumlarında ve farmasötik dozaj formlarında L-Dopa' nın belirlenmesi için güvenilir bir sıvı kromatografik metod geliştirilmiştir. Analizler Ace C18 (5 m, $4.6 \times 250$ mm,) kolon kullanılarak yapıldı ve ayırma, $1.2 \mathrm{~mL} \mathrm{~min}^{-1}$ akış hızında 50 $\mathrm{mM}$ potassium dihydrogen phosphate $(\mathrm{pH}$ 2.3) içeren bir mobil faz kullanılarak $280 \mathrm{~nm}$ de UV deedektör ile gerçekleştirildi. Metod, $\mathrm{ICH}$ yönergelerinin kabul kriterlerine göre valide edilmiştir. Metod, analiz edilen konsantrasyon aralığında iyi doğrusallık ( $\left.R^{2}>0.999\right)$, gün içi ve günler arası kesinlik gösterdi. L-Dopa için teşhis limiti (LOD) ve tayin limiti (LOQ) değerleri 1.70 ve $5.13 \mu \mathrm{g} \mathrm{mL} \mathrm{L}^{-1}$ olarak belirlenmiştir. Geliştirilen metod, ilaç formülasyonlarında ve bitki materyallerinde L-Dopa' nın belirlenmesi için başarıyla kullanılmıştır.
}

\section{Anahtar Kelimeler}

L-Dopa, HPLC-UV, metod, validasyon, bitki materyali.

Article History: Received Jul 25, 2020; Revised: Sep 27, 2020; Accepted: Sep 29, 2020; Available Online:Oct 20, 2020. DOI: https://doi.org/10.15671/hjbc.773988

Correspondence to: I. Bulduk, Department of Chemistry, Uşak University, Uşak, Turkey.

E-Mail: ibrahim.bulduk@usak.edu.tr 


\section{INTRODUCTION}

During the last few years, new medicines have become available for treating Parkinson's disease. Nevertheless, L-Dopa has been regarded as a gold standard treatment for motor symptoms since the administration of dopamine supplementation [1-3]. L-Dopa is a natural precursor of dopamine and is used as a prodrug, as it may cross the brain-blood barrier, contrary to dopamine. The chemical properties of L-Dopa have been given in Table 1 [4].

Long-term use of L-Dopa leads to motor problems and variations such as the 'wearing-off' condition characterized by moments without the benefits of therapy and moments with its advantages but with additional dyskinesia. Research has shown that high L-Dopa doses have also been associated with patient dyskinesia [5-7]. Therefore, it is recommended that doses of L-Dopa be modified according to the patient's individual needs based on clinical response and adverse event profile [1]. Several analytical methods for the determination of L-Dopa and its metabolites in biological matrices have been identified in the literature using high-performance liquid chromatography and various detection techniques such as electrochemical detection [8-16], tandem mass spectrometry (MS-MS) [17-22], and fluorescence $[23,24]$. Most of the above-mentioned methods have a common low sensitivity limitation and time consuming chromatographic separation.

Therefore, the purpose of this study was to develop and validate a robust and efficient HPLC method to determine the amount of L-Dopa in drug formulations in a pharmaceutical laboratory for the routine quality control study. The pharmaceutical industries use the time- consuming LC method and various mobile phases for different dosage forms of drugs. But with the system being developed, the cost and time required to adjust mobile phases could be avoided, as only one mobile phase could be used for all drugs and their combinations. The method should be applied from drug release experiments with prototypes and marketed fixed-dose combinations and to determine the number of samples under compendial testing conditions. Hence the method needs to be robust against matrix effects caused by formulation excitements.

\section{MATERIALS and METHODS}

\section{Reagents}

All of the chemicals were used without further purification in this study. L-Dopa standard was acquired from Sigma-Aldrich (Istanbul, Turkey). Pharmaceutical tablets were bought from local pharmacies. Potassium dihydrogen phosphate, orthophosphoric acid, and triethylamine have been purchased from Merck Ltd. Ultrapure water was obtained using a Milli-Q System with conductivity lower than $0.05 \mu \mathrm{S} \mathrm{cm} \mathrm{cm}^{-1}$. All other chemicals were of analytical reagent grade.

\section{Determination of $\boldsymbol{\lambda}_{\text {max }}$}

$20 \mu \mathrm{g} \mathrm{mL}^{-1}$ standard solution of L-Dopa in ultrapure water was scanned on a UV spectrophotometer (Shimadzu UV-1800 spectrophotometer). $\lambda$ max was obtained from the UV spectrum of L-Dopa.

\section{Chromatographic Conditions}

HPLC analysis was performed on an Agilent 1260 HPLC system (Agilent Technologies, USA), equipped with binary pump, auto sampler, vacuum degasser, thermostatted column compartment, UV detector, and Chems-

Table 1. The chemical properties of L-Dopa.

\begin{tabular}{c} 
The chemical properties \\
3 Structure of molecules \\
\hline The formula of molecular: \\
\hline The weight of the molecules \\
$\left(\mathrm{g} \mathrm{mol}^{-1}\right)$ :
\end{tabular}




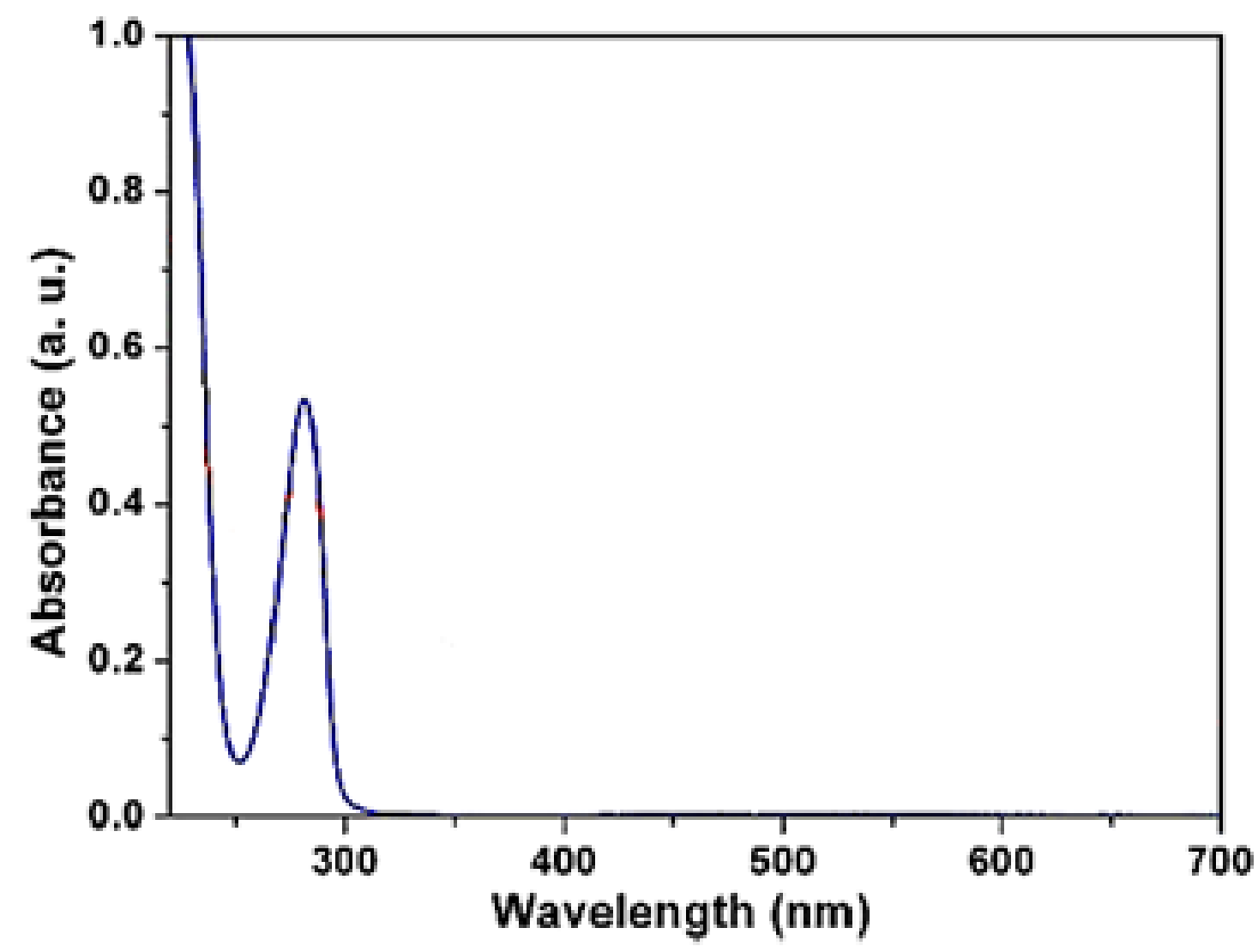

Figure 1.Designed target molecule compared with econazole.

tation software. Chromatographic analysis was carried out on a column Ace 5 C18 (250 x $4.6 \mathrm{~mm}, 5 \mu \mathrm{m})$. The mobile phase was $50 \mathrm{mM}$ potassium dihydrogen phosphate $(\mathrm{pH}$ 2.3). For buffer solution: $6.80 \mathrm{~g}$ potassium dihydrogen phosphate was accurately weighed. The volume was completed in liters by dissolving in deionized water. $5 \mathrm{ml}$ of triethylamine was added. The $\mathrm{pH}$ of the obtained solution was adjusted to 2.3 by adding orthophosphoric acid. The mobile phase was filtered through a $0.45 \mu \mathrm{m}$ membrane filter and degassed before use. Chromatographic analysis was carried out at a temperature of $30{ }^{\circ} \mathrm{C}$ using a flow rate of $1.2 \mathrm{~mL} \mathrm{~min}^{-1}$ and a run time of $10 \mathrm{~min}$. The injection volume was $20 \mu \mathrm{L}$, and the wavelength was set at $280 \mathrm{~nm}$. The mobile phase has been used as a diluent and blank preparation.

\section{Preparation of Standard Solutions}

The standard of $100.00 \mathrm{mg}$ L-Dopa was accurately weighed and transferred to a $100 \mathrm{~mL}$ volumetric flask (Class A), and mixed with $35 \mathrm{~mL}$ of deionized water, dissolved in an ultrasonic bath until a clear solution was obtained, equilibrated to room temperature $\left(\sim 24^{\circ} \mathrm{C}\right)$ and, completed to volume with deionized water. This prepared solution was called as stock standard solution. Standard solutions were prepared by diluting from stock standard solution with ultrapure water so that the final L-Dopa concentration was 20, 40, 60, 80 and 100 $\mu \mathrm{g} \mathrm{mL}^{-1}$.

\section{Preparation of Sample}

L-Dopa is an amino acid that dissolves well in water. Ten of tablets were weighed and crushed in mortar and ground into fine powder. Powder samples equal to $\sim 50 \mathrm{mg}$ of L-Dopa were placed in a $500 \mathrm{~mL}$ volumetric flask, diluted with $200 \mathrm{~mL}$ of deionized water and dissolved in an ultrasonic bath for 30 minutes. It was equilibrated at room temperature $\left(\sim 24^{\circ} \mathrm{C}\right)$ and, completed to volume with deionized water. All samples were filtered through a $0.45 \mu \mathrm{m}$ Millipore Millex-HV filter before injection.

$1 \mathrm{~g}$ of the leaves, flowers and fruits of the dried, ground Vicia faba L. is carefully weighed separately and $50 \mathrm{ml}$ of boiling deionized water is added. It was extracted in an ultrasonic bath with duration of $15 \mathrm{~min}$. It was filtered 
through white filter paper. The extracts were stored in the fridge until analysis.

\section{Validation Procedure}

L-Dopa solution, $20 \mathrm{mg} \mathrm{mL}^{-1}$ in deionized water, was tested by the UV spectrophotometer. $\lambda$ max was determined as $280 \mathrm{~nm}$ from the UV spectrum of L-Dopa (Figure 1).

The validation study was conducted in accordance with the recommendations for validation of the International Conference on Harmonization [25, 26]. Parameters analyzed include linearity, accuracy, precision, the limit of detection (LOD), limit of determination (LOQ), specificity, the suitability of the system and robustness. During the method validation, parameters were studied as the specificity, linearity, accuracy, precision and suitability of the system, robustness, detection limit (LOD) and quantification limit (LOQ).

The new HPLC method was primarily designed for measuring high drug loads and the release of drugs. However, the method should also be applied in routine testing as much as possible, for instance for testing pharmaceutical formulations. For the second reason, the method must ensure that the drug is properly identified within a broad range of concentrations. A specific concentration range was selected for the validation procedure based on those considerations. Accordingly, the concentration range for L-Dopa was selected as $20-100 \mu \mathrm{g} \mathrm{mL}^{-1}$ for method validation.

The specificity which is an essential part of the validation of the method has been assessed as follows: First, a certain amount of L-Dopa was dissolved in a known amount of ultra-pure water and a stock standard solution was prepared at the concentration of $1000 \mathrm{mg}$ $\mathrm{L}^{-1}$. Different concentrations of standard solutions were prepared by dilution from prepared stock standard solution with ultra-pure water. Then, the impact of excipients used in the manufacture of the selected marketed dosage forms on the proper assessment of L-Dopa peak was screened. After sample analysis, the chromatograms were assessed for peak area and excipient interference at retention periods of L-Dopa.

The linearity of the analytical method was determined by preparing and injecting standard solutions in the range of 20 to $100 \mu \mathrm{g} \mathrm{mL}^{-1}$ of L-DOPA solution. The calibration curve was formed by drawing the peak area against the concentration of L-Dopa and the regression equation slope and intercept point was calculated. Each solution was injected six times.

The accuracy and recovery of the method were determined by calculating recoveries by the spiking method. A known amount of standard solutions of $10,40,120 \mu \mathrm{g} \mathrm{mL}^{-1}$ were spiked to a known amount of sample solutions $(40 \mu \mathrm{g}$ $\left.\mathrm{mL}^{-1}\right)$. The amount was estimated by the regression equation of the calibration curve.

The precision has been assessed on the method's repeatability and reproducibility. The intra-day repeatability has been assessed on the same day by determining the relative standard deviation (RSD \%) of the areas obtained from the injection of six standard solutions replicates (L-Dopa concentration, $40 \mu \mathrm{g} \mathrm{mL}{ }^{-1}$ ). The same standard was injected one time per day during a period of six nonconsecutive days in the reproducibility assessment (interday repeatability)

The detection limit (LOD) of the drug is a characteristic value for the precision of the method in which the corresponding compound is only measurable, whereas the quantitation limit (LOQ) is the lowest concentration with acceptable linearity, accuracy, and certainty. Linearity range was satisfactory for analyses of L-Dopa in pharmaceuticals and plant materials. In this method, the LOD and LOQ levels were calculated by standard deviation of the calibration curve.

The suitability of the system was assessed by determining the tailing factor and the reproducibility of peak areas and retention times. Additionally, for this analyte, calibration curves were established and linearity checked.

Various method parameters were tested to assess the reliability and robustness of the proposed HPLC method. The self-imposed parameters limits set for these parameters have been inspired by other publications and our experience. We studied parameters as follows: The flow of the mobile phase $\left( \pm 0.10 \mathrm{~mL} \mathrm{~min}{ }^{-1}\right)$, column temperature $( \pm$ $\left.5^{\circ} \mathrm{C}\right)$, buffer concentration $( \pm 0.01 \mathrm{M})$ and $\mathrm{pH}$ value $( \pm 0.10)$ for the mobile phase. It was investigated these parameters by injecting a series of dilutions with three individual standards for lowest, medium and highest concentrations of L-Dopa in triplicate. The robustness of the system has been measured by absolute average recovery, RSD (precision) and $R^{2}$ of the calibration curves that resulted. 


\section{RESULTS and DISCUSSION}

Development of the method

Several preliminary studies were conducted to optimize the chromatographic conditions for the quantification of L-Dopa. Mobile phases consisting of several buffer systems were tried at the beginning of the study, they could not meet the required system parameters.

A phosphate buffer ( $\mathrm{pH}$ of 2.30) was chosen as a mobile phase based on these criteria. Furthermore, the chosen eluents have been designed for solvent $\mathrm{pH}$ and ionic resistance. The mobile phase was $0.050 \mathrm{mM}$ potassium dihydrogen phosphate $(\mathrm{pH}: 2.3)$. For buffer solution: $6.80 \mathrm{~g}$ potassium dihydrogen phosphate was accurately weighed. The volume was completed in liters by dissolving in deionized water. In order to decrease the tailing of L-Dopa peak $0.5 \%$ triethylamine (TEA) was used as ion pairing agent in the mobile phase. $5 \mathrm{ml}$ of triethylamine was added. The $\mathrm{pH}$ of the obtained solution was adjusted to 2.3 by adding orthophosphoric acid.

HPLC analysis was carried out on a column Ace 5 C18 (250 x $4.6 \mathrm{~mm}, 5 \mu \mathrm{m})$. Appropriate volume for injection and column temperature were selected and the initial isocratic program was also modified step by step. Mobile phase running at different flow rates $0.5-1.5 \mathrm{~mL}$ $\mathrm{min}^{-1}$ ) and $\mathrm{pH}$ ranges were tested. Chromatographic analysis was conducted at $30^{\circ} \mathrm{C}$ with a flow rate of 1.2 $\mathrm{mL} \mathrm{min}-1$ and a run time of $10 \mathrm{~min}$. The injection amount was $20 \mu \mathrm{L}$, and ultraviolet measurements were at 280 $\mathrm{nm}$. The mobile phase was used as a blank and diluent preparation.

The sample solution was analyzed for 60 minutes to ensure that there were no matrix components remaining in the column for much longer under the specified conditions. However, continuing the analysis after 10 minutes will increase both analysis time and cost. Overlapping peaks were not observed to overlap in samples from sample analyses injected into the system consecutively with 10 minutes of analysis time. Due to all these, the analysis time was determined as $10 \mathrm{~min}$.

\section{Specificity}

The new method's specificity was evaluated by first analyzing blank solvents/media, and then samples

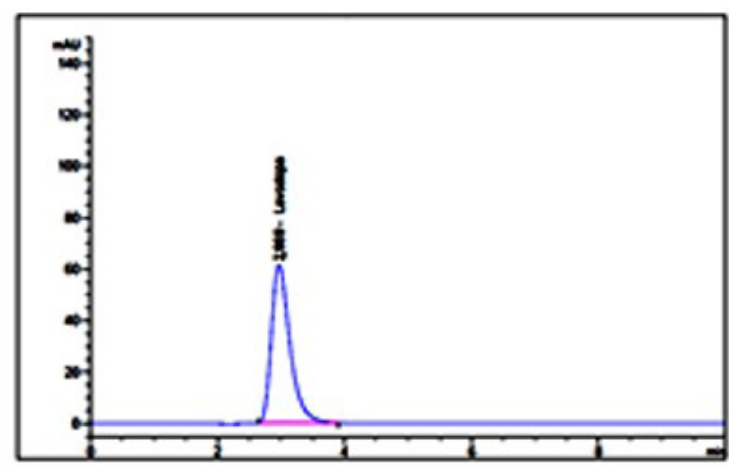

$\mathbf{B}$

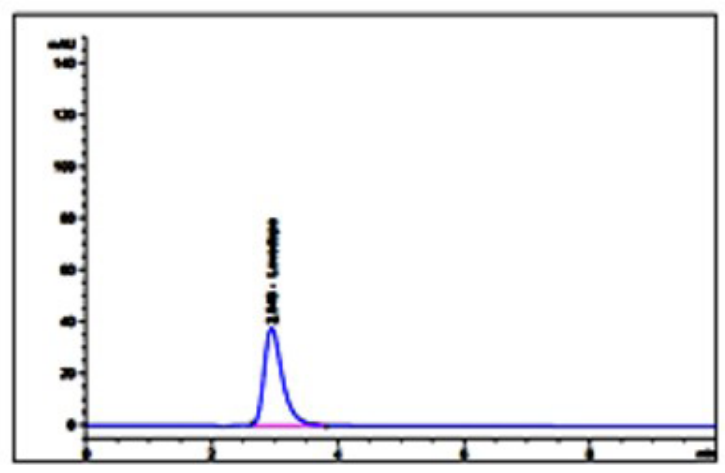

D

Figure 2. Chromatogrames A. Blank B. L-Dopa standard solution. C. Pharmaceutical sample. D. Plant material. 
containing a single combination of drugs or drugs. The process showed good separation of the compound in standard solutions by chromatography (L-Dopa reference material dissolved in ultrapure water). No peak interference was observed between the analytes with blank media, buffer components or excipients of the marketed dosage formulations. Interference studies were shown by injection of blank, sample and standard solution. No drug excipient interactions were observed. There was no peak at the retention time of L-Dopa ( $F i$ gures $2 \mathrm{~A}$ and $2 \mathrm{~B}$ ). This indicates that the blank and drug excipients did not interfere. The retention time was 2.9495 min for L-Dopa. The chromatogram of the drug sample and extract of the plant material is presented in Figure 2C, 2D.

\section{Linearity}

The solutions for the linearity test were prepared from the solution of L-Dopa at five different levels of concentration ranging from $20-100 \mu \mathrm{g} \mathrm{m}^{-1}$. The calibration curve was created by plotting the substance area versus the concentration. The correlation coefficients, slopes and $y$-intercepts of the calibration plots were obtained and reported in Figure 3. The mean linear regression equation of the calibration curves was calculated as $y$ $=12.419 x+2.153\left(r^{2}=0.9999\right)$. The limit of detection (LOD) and the limit of quantitation (LOQ) were calculated according to the following equation: LOD or LOQ $=\mathrm{kSDa} / \mathrm{b}$, where 10 for $\mathrm{LOQ}$ and $\mathrm{k}=3$ for LOD, SDa represents the standard deviation of the intercept, and $b$ represents the slope. The LOD was $1.70 \mu \mathrm{g} \mathrm{mL}^{-1}$ and the LOQ was determined as $5.13 \mu \mathrm{g} \mathrm{mL}^{-1}$.

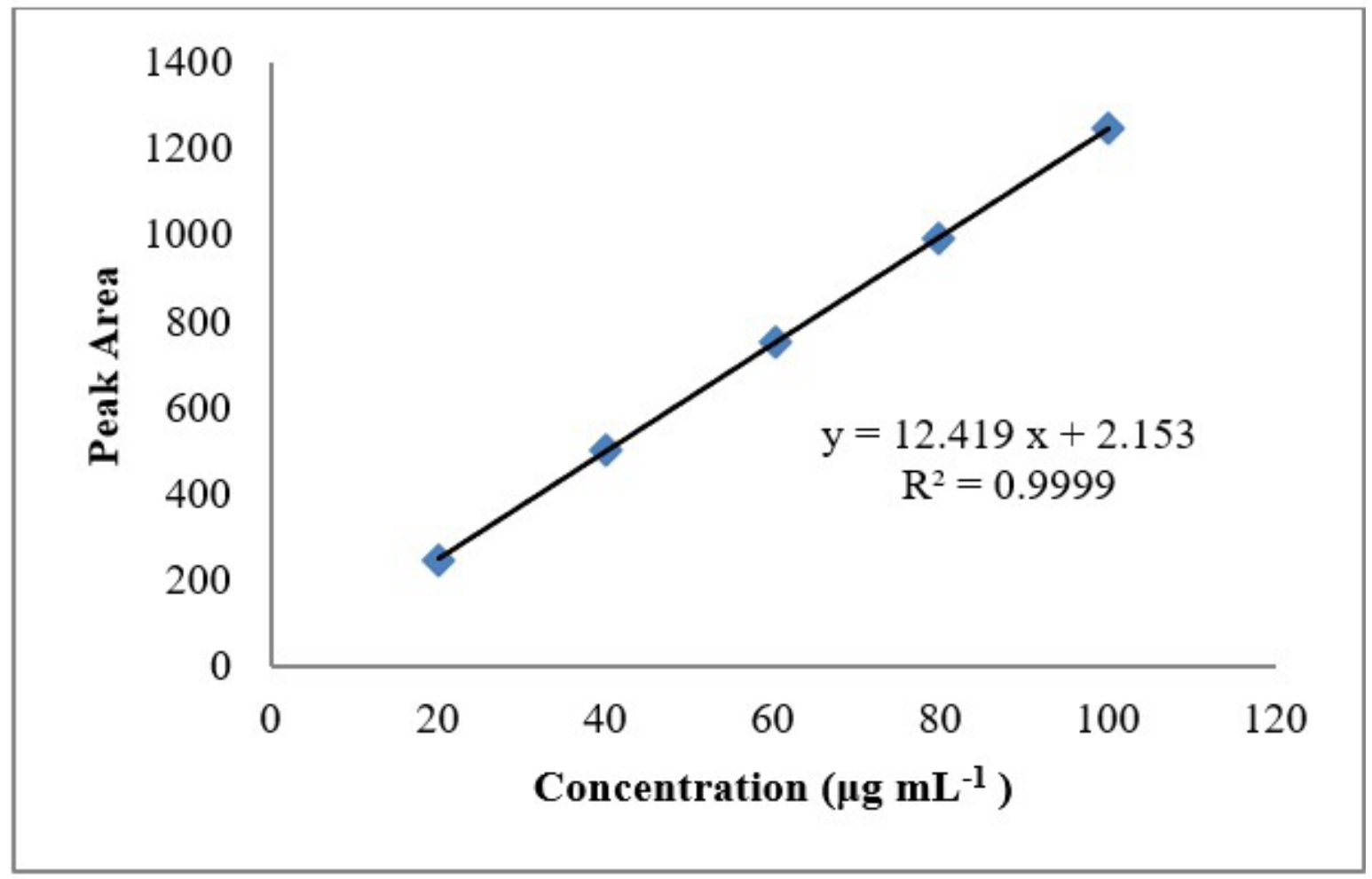

Figure 3. Calibration curve for L-Dopa standard solutions (at $280 \mathrm{~nm}$ ). 
Table 2. Summary of validation data of developed HPLC-UV method

\begin{tabular}{cc}
\hline Parameter & Value \\
\hline RT $(\mathrm{min})$. & 2.9495 \\
\hline Linear range $\left(\mu \mathrm{g} \mathrm{mL}^{-1}\right)$ & $20-100$ \\
\hline Linear regression equation & $\mathrm{y}=12.419 \mathrm{x}+2.153$ \\
\hline Recovery $\%$ & 100.32 \\
\hline Correlation Coefficient $\left(\mathrm{R}^{2}\right)$ & 0.9999 \\
\hline Lack of Fit & \\
\hline $\mathrm{F}$ & 3.14 \\
\hline $\mathrm{P}$ & 0.555 \\
\hline SD of Intercept $I n t e r c e p t$ & 5.8312 \\
\hline LOD/LOQ $\left(\mu \mathrm{g} \mathrm{mL}^{-1}\right)$ & 13.2215 \\
\hline
\end{tabular}

\section{Accuracy}

The standard addition technique was carried out to prove the accuracy of the proposed method. After adding a certain amount $\left(40 \mu \mathrm{g} \mathrm{mL}^{-1}\right)$ of pure sample solution to the $10,40,120 \mu \mathrm{g} \mathrm{mL} \mathrm{L}^{-1}$ concentrations of standard L-Dopa solutions, the analysis were performed. The percentage recoveries for the drug ranged from 100.08$100.41 \%$. The results of the recovery study have been presented in Table 3.

\section{Precision}

The precision was expressed as relative standard deviation $(\mathrm{RSD} \%=\mathrm{SD} / \mathrm{mean} \times 100)$. The relative standard deviation (RSD) of the calibration standards $(n=6)$ for intra-day precision (repeatability) and inter-day (intermediate) precision were $1.19 \%$ and $3.80 \%$, respectively (Table 4).

In our case the presented HPLC method establishes that RSD \% values less than 5 that are acceptable and below $10 \%$ (for reproducibility). Our data is suitable our method for validation requirements.

Table 3. Accuracy of the HPLC Method.

\begin{tabular}{ccccc}
\hline $\begin{array}{c}\text { Nominal value } \\
\text { L-Dopa } \\
\left(\mu \mathrm{gL}^{-1}\right)\end{array}$ & $\begin{array}{c}\text { Spiked amount } \\
\left(\mu \mathrm{g} \mathrm{m}^{-1}\right)\end{array}$ & $\begin{array}{c}\text { Measured amounta } \\
\left(\mu \mathrm{g} \mathrm{mL} \mathrm{L}^{-1}\right) \\
\left(\text { Mean } \pm \text { S.D. } .^{\mathrm{b}}\right)\end{array}$ & Recovery (\%) & RSD (\%) \\
\hline $\mathbf{4 0}$ & 10 & $50.04 \pm 0.06$ & 100.08 & 0.12 \\
\hline & 40 & $80.27 \pm 0.37$ & 100.34 & 0.46 \\
\hline
\end{tabular}

${ }^{\mathrm{a}}$ Five independent analyses.

bStandard deviation 
8 i. Bulduk and N. Topal / Hacettepe J. Biol. \& Chem., 2021, 49 (1), 1-10

Table 4. Precision of the HPLC Method.

\begin{tabular}{|c|c|c|c|c|}
\hline \multirow[t]{2}{*}{ Compound } & \multicolumn{2}{|c|}{ Repeatability(n=6) } & \multicolumn{2}{|c|}{ Reproducibility $(n=6)$} \\
\hline & Mean $\pm S D$ & RSD, $\%$ & Mean $\pm S D$ & $\mathrm{RSD}, \%$ \\
\hline L-Dopa & $40.07 \pm 0.48$ & 1.19 & $40.78 \pm 1.55$ & 3.80 \\
\hline
\end{tabular}

SD: Standard deviation; RSD: Relative standard deviation

\section{System suitability}

Primary parameters to evaluate system suitability such as symmetry factor, retention factor were determined for the lowest $\left(40 \mu \mathrm{g} \mathrm{mL}^{-1}\right)$, medium $\left(60 \mu \mathrm{g} \mathrm{mL} \mathrm{L}^{-1}\right)$ and highest $\left(80 \mu \mathrm{g} \mathrm{mL}^{-1}\right)$ concentrations for this analytes and were listed in Table 5. L-Dopa had excellent peak symmetry. In addition, the peaks of the analytes showed consistently low variability in peak areas and retention times. Calibration curve coefficient in this study was above 0.999, which indicates that the method was suitable for samples with simple or rather complex matrices.

\section{Robustness}

The robustness study data show that the linearity, absolute mean recovery, and precision of the developed method remain unaffected by small changes in critical method parameters. The corresponding results have been shown in Table 6. Temperature variations, flow rate, ionic strength, and $\mathrm{pH}$ value did not affect this analyte's recovered amount. The absolute mean drug recovery for all substances was between $99 \%$ and $101 \%$ and the level of RSD was less than $1.00 \%$.

Table 5. Results for system suitability

\begin{tabular}{cccc}
\hline \multirow{2}{*}{$\begin{array}{c}\text { System suitability } \\
\text { parameters }\end{array}$} & \multicolumn{3}{c}{$\begin{array}{c}\text { Std. Solution Conc. } \\
\mu \mathrm{g} \mathrm{mL}^{-1}\end{array}$} \\
\cline { 2 - 4 } & 40 & 60 & 80 \\
\hline Symmetry factor & 0.6597 & 0.6530 & 0.6576 \\
\hline Peak areas (\% RSD) & 0.1685 & 0.1527 & 0.1432 \\
\hline Retention times (\% RSD) & 0.0597 & 0.0536 & 0.0521 \\
\hline
\end{tabular}

Table 6. Results for robustness

\begin{tabular}{cccc}
\hline \multirow{2}{*}{$\begin{array}{c}\text { Robustness } \\
\text { Parameters }\end{array}$} & Parameter Value & Abs. Mean Recovery \% & RSD \\
\hline \multirow{2}{*}{ Mobile phase flow rate } & $1.10 \mathrm{~mL} \mathrm{~min}^{-1}$ & 100.34 & 0.12 \\
\cline { 2 - 4 } & $1.30 \mathrm{~mL} \mathrm{~min}^{-1}$ & 99.88 & 0.05 \\
\hline \multirow{2}{*}{ Column temperature } & $25 \mathrm{OC}$ & 99.76 & 0.07 \\
\hline \multirow{2}{*}{ Buffer concentration } & $350 \mathrm{C}$ & 100.21 & 0.18 \\
\hline \multirow{2}{*}{ pH value } & $0.040 \mathrm{M}$ & 100.86 & 0.93 \\
\hline & $0.060 \mathrm{M}$ & 99.91 & 0.64 \\
\hline
\end{tabular}


Table 7. L-Dopa contents of flowers, leaf and seed

\begin{tabular}{cccc}
\hline Sample & Flowers \pm SD & Leaf \pm SD & Seed \pm SD \\
\hline L-Dopa mg g $^{-1}$ & $52.21 \pm 0.07$ & $34.45 \pm 0.14$ & $7.68 \pm 0.18$ \\
\hline
\end{tabular}

SD: Standard deviation

Determination of L-Dopa content in different parts of Vicia faba L.

L-Dopa contents of flowers, leaf and seed were analyzed by validated HPLC method were presented in the table 7.

\section{Determination of L-Dopa in the pharmaceutic formulations}

The proposed method was applied in the pharmaceutical forms to quantitatively evaluate L-Dopa. The obtained results were in the agreement with the results specified in the approved labeled content of L-Dopa (Table 8).

Table 8. Determination of L-Dopa in tablets by the proposed methods $(n=5)$.

\begin{tabular}{ccccc}
\hline & $\begin{array}{c}\text { Label claim } \\
(\mathrm{mg} / \text { per tablet })\end{array}$ & Mean \pm S.D & Recovery (\%) & RSD (\%) \\
\hline Proposed method & 250 & $250.38 \pm 1,35$ & 100.15 & 0.54 \\
\hline
\end{tabular}

aSINEMET ${ }^{\oplus} 250 \mathrm{mg}$ Tablet

\section{Conclusions}

A HPLC method for an effective analysis of L-Dopa in plant material and pharmaceutical formulations was developed and validated. There was no significant difference in the statistical comparison of the assay results for L-Dopa in tablet dosage forms and plant material by this method. The method allows a fast and robust quantification without any interference caused by formulation excipients or ingredients. The findings of the tablet dose study according to the analytical method are reliable, reproducible, and are in good agreement with drug label claims. Therefore this method can be used successfully in tablet dosage forms and plant materials for routine analysis of L-Dopa.

\section{Acknowledgments}

This study was supported by Uşak University. Thanks for their support.

\section{References}

1. S. Fahn, D. Oakes, I. Shoulson, K. Kieburtz, A. Rudolph, A Lang, C.W. Olanow, C. Tanner, K. Marek, L-DOPA and the progression of Parkinson's disease, New Engl. J. Med., 351(2004) 2498-2508.

2. C.E. Clarke, M. Guttman. Dopamine Agonist Monotherapy in Parkinson's Disease. Lancet, 360 (2002) 1767-1769.

3. M. Rezak, Current pharmacotherapeutic treatment options in Parkinson's disease, Dis. a Month, 53 (2007) 214-222.

4. https://www.drugbank.ca/drugs/DB00190

5. D. Goncalves, G. Alves, P. Soares-da-Silva, A. Falcão, Bioanalytical chromatographic methods for the determination of catechol-O-methyltransferase inhibitors in rodents and human samples: a review, Anal. Chim. Acta, 710 (2012) 17-32.

6. https://www.drugbank.ca/drugs/DB00190

7. F.J. David, M.R. Rafferty, J.A. Robichaud, J. Prodoehl, W.M. Kohrt, D.E. Vaillan-court, D.M. Corcos, Progressive resistance exercise and Parkinson's disease: a review of potential mechanisms, Parkinson's Dis, (2011) 124527.

8. J.M. Cedarbaum, R. Williamson, H. Kutt, Simultaneous determination of L-DOPA, its metabolites and carbidopa in clinical samples, J. Chromatogr. B: Biomed. Sci. Appl., 415 (1987) 393-399.

9. Y. Michotte, M. Moors, D. Deleu, P. Herregodts, G. Ebinger, Simultaneous Determination of Levodopa, Carbidopa, 3-O-methyldopa and dopamine in plasma using highperformance liquid chromatography with electrochemical detection, J. Pharm. Biomed. Anal., 5 (1987) 659-664.

10. D.C. Titus, T.F. August, K.C. Yeh, R. Eisenhandler, W.F. Bayne, D.G. Musson, Simultaneous high-performance liquid chromatographic analysis of carbidopa, L-DOPA and 3-O-methyldopa in plasma and carbidopa, L-DOPA and dopamine in urine using electrochemical detection, J. Chromatogr. B: Biomed. Sci. Appl., 534 (1990) 87-100. 
11. K.A. Sagar, M.R. Smyth, Simultaneous determination of L-DOPA, carbidopa and their metabolites in human plasma and urine samples using LC-EC, J. Pharm. Biomed. Anal., 22 (2000) 613-624.

12. V. Rizzo, M. Memmi, R. Moratti, G. Melzi d’Eril, E. Perucca, Concentrations of L-Dopa in plasma and plasma ultrafiltrates. J. Pharm. Biomed. Anal., 14 (1996) 1043-1046.

13. T. Wikber, Simultaneous determination of L-DOPA, its main metabolites and carbidopa in plasma by liquid chromatography, J. Pharm. Biomed. Anal., 9 (1991) 167-176.

14. M. Karimi, J.L. Carl, S. Loftin. J.S. Perlmutter, Modified highperformance liquid chromatography with electrochemical detection method for plasma measurement of L-DOPA, 3-O-methyldopa, dopamine, carbidopa and 3,4-dihydroxyphenyl acetic acid. Journal of chromatography. $B$, Analytical Technologies in the Biomedical and Life Sciences, 836 (2006) 120-123.

15. F. Bugamelli, C. Marcheselli, E. Barba, M.A. Raggi, Determination of L-dopa, carbidopa, 3-O-methyldopa and entacapone in human plasma by HPLC-ED. Journal of Pharmaceutical and Biomedical Analysis, 54 (2011) 562-567.

16. M. Kuoppamaki, K. Korpela, R. Marttila, V. Kaasinen, P. Hartikainen, J. Lyytinen, S. Kaakkola, J. Hanninen, E. Loyttyniemi, M. Kailajarvi, P. Ruokoniemi, J. Ellmen, Comparison of pharmacokinetic profile of L-DOPA throughout the day between L-DOPA/carbidopa/ entacapone and L-DOPA/carbidopa when administered four or five times daily, Eur. J. Clin. Pharmacol. 65 (2009) 443-455.

17. R.M.D. d.C.I. César, F.F. Byrro, I.M. de Santana e Silva Cardoso, L. Mundim, E. de Souza Teixeira, S.A. Pontes da Silva, R.R. Gomes, G.A. Bonfim, Simultaneous quantitation of L-DOPA and 3-Omethyldopa in human plasma by HPLCESI-MS/MS: Application for a pharmacokinetic study with a L-DOPA/benserazide formulation, J. Pharm. Biomed. Anal., 56 (2011) 1094-1100
18. H.F. Martins, D.P. Pinto, d.A.V. Nascimento, M.A.S. Marques, F.C. Amendoeira, Development of an HPLC/MS/MS methodology for determining 3-Omethyldopa in human plasma and its application in a bioequivalence study, Quím. Nova, 36 (2013) 171-176.

19. K. Igarashi, K. Hotta, F. Kasuya, K. Abe, S. Sakoda, Determination of cabergoline and L-Dopa in human plasma using liquid chromatography-tandem mass spectrometry, J. Chromatogr. B, 792 (2003) 55-61.

20. R.R. Gonzalez, R.F. Fernandez, J.L. Vidal, A.G. Frenich, M.L. Perez, Development and validation of an ultrahigh performance liquid chromatography-tandem massspectrometry (UHPLC-MS/MS) method for the simultaneous determination of neurotransmitters in rat brain samples, Neurosci. Methods, 198 (2011) 187-194.

21. P.O. Cinto, A.L.R.S. Souza, A.C. Lima, M.V. Chaud, M.P.D. Gremião, LC Evaluation of Intestinal Transport of Praziquantel. Chromatographia, 69 (2009) 213-217.

22. F. Gosetti, E. Mazzucco, M. Gennaro, E. Marengo, Simultaneous determination of sixteen underivatized biogenic amines in human urine by HPLC-MS/MS. Anal. Bioanal. Chem., 405 (2013) 907-916.

23. C. Muzzi, E. Bertocci, L. Terzuoli, B. Porcelli, I. Ciari, R. Pagani, R. Guerranti, Simultaneous determination of serum concentrations of L-DOPA, dopamine, 3-O-methyldopa and a-methyldopa by HPLC, Biomed. Pharmacother, 62 (2008) 253-258.

24. H.X. Zhao, H. Mu, Y.H. Bai, H. Yu, Y.M. Hu, A rapid method for the determination of dopamine in porcine muscle by pre-column derivatization and HPLC with fluorescence detection, J. Pharm. Anal., 1 (2011) 208-212.

25. International Conference on Harmonization (ICH) of Technical Requirements for the Registration of Pharmaceuticals for Human Use, validation of analytical procedures: Methodology, The 6th International Conference on Harmonization, Geneva, 2003.

26. R. Hadjikinova, N. Petkova, D. Hadjikinov, P. Denev, D. Hrusavov, Development and validation of hplc-rid method for determination of sugars and polyols, J. Pharm. Sci. \& Res., 9 (2017) 1263-1269. 